\title{
Awareness and Acceptance Of Genetic Modified Food (GMF) Among The Malaysian Consumers
}

\author{
Azlin A.M.Z. ${ }^{1}$, Jamaluddin R, Baki R, Enio M.S.K. ${ }^{1}$, J. Ho Abdullah, S. ${ }^{2}$ \\ ${ }^{1}$ Faculty of Education, Universiti Putra Malaysia, ${ }^{2}$ Faculty of Environment, Universiti Putra Malaysia
}

The halal industry is growing vigorously to cater the Muslim consumers in Malaysia. The acceptance, awareness and perception towards the genetic modified food (GMF) is still insufficient to fulfil the Malaysian market and expectantly plays a major role in a long period. The purpose of this paper is to fill the knowledge gap to the study of GMF conducted in Malaysia. Qualitative data were collected via open-ended interview with four participants from various background namely Malaysian Agricultural Research and Development Institute (MARDI) researcher, P3, P4 and P1 by using single case and different site. All interviews were audio recorded, transcribed and analysed. Almost all participants familiar with the term genetic modified organism (GMO) or genetic modified food (GMF) which are two different entities but similar in biotechnology scope. Almost all participants were $f$ amiliar with the term of genetic modified food. Since most of the participants came out with the science and biotechnology background, they perceived the GMF product but some of them did not trust of these products for various reasons. The participants agreed on the need for more information from a trusted and credible source that can easily access by the consumers. This study provides an in-depth insight into consumer' awareness, perception and evaluation concerning the halalan toyyiban status of genetic modified food in Malaysia. To date, only few of this study is reported locally. The novelty of these finding could provide information for the biotechnology food industry to expand its market and dev develop its profitability and reliability to promo sustainable food production and consumption in the population.

Keywords: genetic modified food (GMF), genetic modified organism (GMO), consumers, biotechnology

Received: November 18, 2019 Accepted: February 26, 2020 Published: March 4, 2020

Citation: A.M.Z. A, R J, RB, M.S.K. E and Ho Abdullah, S. J (2020) Awareness and Acceptance Of Genetic Modified Food (GMF) Among The

Malaysian Consumers.

Awareness and Acceptance Of

Genetic Modified Food (GMF) Among The Malaysian Consumers.

doi: http://doi.org/10.21070/jbmp.v $6 i 1.424$

\section{INTRODUCTION}

Genetic Modified Food (GMF) leads an imperative role in the food supply industry by opening a new frontier to mankind for a better sustainable world. Currently, the agricultural technology is capable in producing novel crops which possess desirable traits and potential to sustainably meet global demand for food and has the ability to thrive in a challenging environment (Godfray et al., 2008). Genetic modification (GM) not only surge the food supply but produce crops resistant to pests and diseases besides improving shelf life (Habibi-Najafi, 2006). In this regard, Malaysia is blessed with abundant fertile lands and pertinent climate ideal for agriculture-based economic activities. The Malaysian government visualized agricultural biotechnology as a mean to enhance food production to ensure food security flourish with the establishment of National Biotechnology Policy (NBP) (Ministry of Science, Technology and Innovation, 2005). The NBP comes in three different time frame; Phase I (2005-2010); Phase II (2011-2015); and, Phase 
III (2016-2020) focusing on healthcare, industrial, Research and Development, human capital development, financial infrastructure, legal and regulatory framework, strategic development, agriculture besides government support and commitment (Malaysian Science and Technology Information Centre, 2014).

However, GMF has raised various issues from the Islamic perspective. The use of illegal materials in generating GMFs, environmental risks, altering God's creations and socioeconomic and ethical issues have been raised by National Fatwa Committee (NFC) (Isa, 2013). For example NFC had put forward a fatwa in 1999 that ruled GMF containing pork DNA is illegal. This decision was made after the assessment was done and the NFC members believed that the pork DNA was used to enhance crop yields. As the way out, NFC suggested the use of halal animals gene slaughtered according to the rules of syarak in the production of GMF (NFC, 2011).

The Arabic the word halal is defined as legally permitted or essential as unadulterated food and following the syariah compliance (Fauziah, 2013). The halalan toyyiban concept must be understood in an integrable manner of the internal and external aspects. It is essential the concept must be understood as a benchmark to the quality of GMF involving all parties for instance consumer, government, manufacturer, supplier or entrepreneur. It is vital to maintain toyyib in term of safe, nutritious, healthy and excellence in wholesome (Dahlan-Taylor, 2015).

Halal food should be purified and nutritious, derived from trustworthy and reliable sources that does not involve unjust practices for example uncertain, domination, manipulation of environment or inquisitive with the ecological balance. Therefore, Muslims considered specific religious dietary guidelines should be free from elements that are measured religiously forbidden, not hygienically prepared and the usage of materials and resources that are unjust and unfair (Al Qudsi, 2014).

This study focuses on the awareness, acceptance and perception related to genetically modified food (GMF) by Malaysian consumers. Moreover, there are limited publications on halal and toyyiban GMOs food in Malaysia (Zurina \& Wan Siti Khadijah, 2012; Isa \& Man, 2014; Mohamed Ismail, 2016).

\section{LITERATURE REVIEW OF THE STATUS HALALAN TOYYIBAN IN MALAYSIA}

Regularly, when publics talk about halal, there is a component missing which is toyyib. According to the interview, halal and toyyib have been emphasized in which both concepts need to be applied together. It further added that it is necessary to educate Muslim and non-Muslim consumers on halal and toyyib concepts that relates to safety, dietary content and aesthetic appeal of halal products. In addition, according to Janis (2004) concepts of halal and toyyib were described by the wholesomeness of the food in which covers the permissible requirements of the law of Islam. Failure in any of the concepts would harm the wholesomeness concept of halal food.

Normally the word halal are in tandem with toyyib. Halal and toyyib have been linked together and both perception need to be applied concurrently as referred to the interview. It is important to educate the consumers on halal and toyyib perceptions relating to well-being, nutritive contents and appealing nature of halal products. Janis (2004) stated that the perceptions of halal and toyyib were defined through the wholesomeness of the food in which covers the permitted requirements by the law of Islam. The concept of halal and toyyib would fail and harm the true meaning of the food wholesomeness.

The Malaysian bodies NFC plays an important role to evaluate the application of GMF for basic guidelines in the main references of shariah in order to make decision on the permissible of the application. Therefore, the fatwa regarding halal and toyyib was sought after consultation with the science expert (Isa \& Man, 2014).

According to Abdul Majid et al. (2015), the consumer still has sceptical attitudes towards halal logo and certification, even though industry has found that the logo and status can be a marketing tool for business expansion. The halal validity and traceability need to be established via research and development process namely in small and medium enterprise with support 
from universities and research centres. There are still many areas need to be explored in implementing halal especially in hospitality sector.

Sazelin \& Safiah (2015) proved that the standards and guidelines used by NFC to determine halal food in Malaysia conform to the principles of Islamic law. It restore Muslim consumers' confidence on NFC, with respect to the implementation of the halal standards and procedures. Hence, maintaining continuity and prosperity of the Muslim community in Malaysia.

Since GMF has become a crucial issues especially for religious and governing authorities whom protect the halal aspect of Muslim consumerism. GMF in Malaysia had to do further empirical study on the general acceptance of the product. It would be appropriate at this point to ensure the level of awareness among Malaysia public in regards to the existence of the GMF in local market. Furthermore, the understanding among Malaysian consumers needed to be understood before further evaluation can be done especially on their acceptance, regardless of their religious background (Mohamed Ismail, 2016).

Halal governance sometimes hinders the process of certification. It is difficult for small and medium enterprise to establish halal status. The halal validity and traceability need to be established through research and development process as indicated by Krishnan et al. (2017) in order to strengthen the local halal industry.

\section{METHODOLOGY}

\section{Methodology}

This is a qualitative case study on four respondents (Ritchie \& Lewis, 2003) who work in the industry with reasonable years of experience. The four respondents were chosen by snowballing sampling (Ellard-Gray et. al., 2015; Salganik \& Heckathorn, 2004; Faugier \& Sargeant, 1997). Data was collected by open interview based on the protocols covering the anticipated focus of the study. Each interview lasted between 45 minutes to 60 minutes. All interview were audio recorded, transcribed verbatim and analysis of the data was conducted by MAXQDA ${ }^{\circ}$.

\section{RESULTS}

This section is presented through several sub-topics; Yes we know about it, we choose quality and we don't trust them. All participants are aware about the term genetic modified food and they had heard about it before; P4 for example, could explained it extensively.

It's probably not entirely but what I understand GMF is we modified any agricultural product no matter the food is animals or plants. I'm aware that, GMF is we change the DNA to justify the needs of a food (P1); I think GMF is involve in a modified of genetic transfer of material DNA from an organism for example bacteria, virus, animal or plant to other organism like plant and animal. What I know is $C$ and $S$ product. C products: corn, cereal, cotton and canola while S products: sugar beet and soy bean (P2) It a food derived from organism plus it's DNA is modified (P3); GMF is a genetically modified organism, modified through genetic engineering and put into a host, is a bacteria cell and then this bacteria will produce certain traits that can produce something for beneficial plant.

However, most of the participants are cautious of the GMF although they are accepting it. This is clearly stated by $\mathrm{P} 2$;

I have no objection. I am not against GMF. I think there are certain issues or controversies regarding GMF like side effect towards human health or environmental issues.

Consequently, GMF are perceived as less natural as compared to the conventional counterparts, and participants are less likely to purchase the genetically engineered products; if there are alternatives they would opt for the conventional products.

I'll find the non-GM food that has the same properties as the GM food. I will still prefer the non-GM food.

A positive correlation existed between perceived naturalness and likelihood to purchase of genetically engineered products, indicating that one possible determinant of acceptance is whether the technology is seen as "natural" or not. 
Genetic modification is of course man-made, its non-natural but GMO is naturally occur you can see some simple plant 20-30 years evolve and you can see how it can adapt to environment. What you do in the lab is actually unnatural. We are altering the DNA but it is quite common even in bacteria because the mutation is always happen (P4).

The likelihood to purchase a food product that is genetically engineered, increases if the modification is associated with health and environmental benefits, low cost or increased shelf life.

I would buy GM food if it offers cheap with spectacular benefits compared to non-GM food, such as low cholesterol, more nutritious and promote anti-ageing. Moreover, it should be halal (P2).

The finding by Amin \& Ibrahim (2011) showed that the Malaysian stakeholders have moderate level of awareness, knowledge and engagement with modern biotechnology applications indicating that they were interested and have accessed to some information about modern biotechnology. In Malaysia, media coverage was rather periodic with limited articles written by columnists and anti-GMO reporting.

However, more efforts by relevant bodies and professionals such as the media, government agencies related to biotechnology, academicians and research scientists should be geared to disseminate more information to the general public and religious expert groups on modern biotechnology concepts and issues through the general mass media, pamphlets or public forums. This is important to prepare the Malaysian public in facing the biotechnology era where they have to make informed decisions regarding modern biotechnology issues in their everyday lives.

\section{We Choose Quality}

The participants are receptive of GMF depending on the quality and nutritional factors. This is clearly stated by most participants.

I really open to it. As long as it is for our benefit. Normally people develop GMF for human being not the other way round. There are more benefit of GM food rather than uncertain risk what you see now so I think why not we just focus on the benefit. We can see the benefit clearly that it can increase your health and give more nutrition because when you eat something healthy you can actually keep away from any diseases so you can becomes more healthier. So, if you becoming healthier why you are more concern about the risk (P4); I have no objection. I am not against GMF. I think there are certain issues or controversies regarding GMF like side effect towards human health or environmental issues (P2); I did not reject GMF but as I said earlier, for example, if the food is high in nutrient then I might try. But just like I said, if we saw the vegetables we bought are very fresh with no blemishes, I might decline. I will try, depends on the food (P1); depends, if the food tastes good but the product is scarce in Malaysia so I got limited choice (P3).

Eventhough they are receptive, they are also worried about GMF. The participant do not belief in GM food and they also distrust in the GM food. They don't belief in GM food because they perceived GM food as unsafe. P2 believes that "it gives long-term side effect to our health. Maybe the way we eat also has long-term side effect." It is supported by $\mathbf{P} 3$ who " heard that GMF content increase resistance against infection and disturb our body system."

At the same time, they also distrust the GM food because the information on GMF are not consistent, confusing and probably biased. These have caused doubts and uncertainties as stated by $\mathrm{P} 2$.

\section{DISCUSSION}

The results of the present study showed that participants were familiar with the term "genetic modified food" but worried about the truthfulness of these products since the labelling of the specific GM products are still lacking. It is interesting to note that some of them consumed such foods without realizing that those are genetic modified products. This shows that the term GM food in Malaysia is specifically a techno-jargon that has not been exposed to the consumers. This result is in agreement with previous studies that reported a low familiarity with the term GMF among consumers (Ismail, 2012; Abdul Majid et al., 2015 and Mohamed Ismail, 2016). 
Moreover, there were generally distrustful attitudes and scepticism about GM products, probably due to lack of knowledge about the contents and potential health benefits. Various issues were discussed in connection with the distrust in the functional GM products, in regard to the consumer. One of them was apparent distrust of advertising and food labels. In agreement with the findings of this study, participants acknowledged the need for information about new food innovations through advertising, but they were very sceptical of advertising (Ferdaus Hossain et al., 2003) and due to the high uncertainty in food industry, it was impossible to buy GM products based on advertising messages (Damien et al., 2012).

In contrast, a study of China consumers showed that most respondents were familiar with the concept of GM food. However, the study population was likely to be representative of a more health informed segment of the China population than the general population (Lanqin et al., 2012).

The price hike in global food prices affect Malaysia due to the practice of importing food supplies instead of increasing local food production. The scenario in Malaysia is still dependent on importation of many agricultural products such as fruits, cereals, beef, mutton and dairy stuffs due to consumer demand and limited local production. Therefore, the needs to explore alternative farming methods that escalate production eventually will decrease our dependency towards imported food and significantly benefit local farmers as well as increasing their income.

An important source of information about GM food is likely to be the introduction of the novel products of the technology into the supermarkets. The availability of the products of the technology may be highly influential in developing public attitudes towards the technology, as well as providing information about potential benefits of the technology as eloquently stated by Lyn et al. (1995).

Malaysian government is blessed for having halal certification standards recognised around the world. Many Muslim government need to make a great provision for halal certification and awareness so it would be easier to identify the halalan toyyiban products especially GMF though diverse halal standards around the world. Furthermore, it is important to protect health of people and the environment.

\section{CONCLUSIONS}

Referring to the study strengths and limitations, this qualitative research and finding can provide a better understanding of the consumers' status of halalan toyyiban towards GMF, as well as preferred channels to raise awareness about it. Hence, the evaluation of GMF and Islamic perspective can be conducted based on the perception, awareness and acceptance of the consumers. Various sampling should include different stakeholders in the biotechnology and agricultural field was an added advantage of the current study. The only limitation is all participants were selected from a sample of professional personnel in the related areas, so the findings might not reflect the overall local population that differ based on their different sosio-demographic variables i.e religious, races, age, gender, marital status, area, income and education levels besides socio-economic status e.g farmer, housewife or the religious expert.

\section{REFERENCES}

1. A study on the formulation of fatwa on genetically

2. Abdul Majid, Zainal Abidin, Mohd Abd Majid Tamby Chik. (2015). Issues of Halal Food Implementation in Malaysia souce from https://www.textroad.com/pdf/JAEBS/ J.\%20Appl.\%20Environ.\%20Biol.\%20Sci.,\%205(6S)50-56, \%202015.pdf. Accessed on 29 November 2017.

3. Al Qudsi, S.G. (2014). Awareness and demand for $100 \%$ halal supply chain meat products. Procedia-Social and Behavioral Sciences, 130, 167-178.

4. Amin L. and Ibrahim R. (2011). How aware and knowledgeable are Malaysians of modern biotechnology? Procedia Social and Behavioral Sciences, 15, 3384-3388. 
5. Amy, Ellard-Gray, Nicole, KJ., Melisa, C. and Sara, EC. (2015). Finding the hidden participant: solutions for recruiting hidden, hard-to-reach, and vulnerable populations, International Journal of Qualitative Methods. 1-10.

6. An overview of genetically modified crop and Marcel Djama.

7. Biernacki, P. and Waldorf, D. (1981). Snowball sampling: Problem and techniques of chain referral sampling, Sociological Methods and Research, 10, 141-163.

8. BIOETHICS IN THE MALAY-MUSLIM COMMUNITY IN MALAYSIA:

9. BIOETHICS IN THE MALAY-MUSLIM COMMUNITY IN MALAYSIA:

10. Dahlan-Taylor M. (2015). Good food: Islamic food ethics beyond religious dietary laws, Critical Research on Religion, 3 (3), 250-65.

11. Damien, W. M., John, G. K., Andrea, I. David, K.H., David, F. Ermen and Tim, B. (2012). Social Stigma and Consumer Benefits Trade-Offs in Adoption of Genetically Modified Foods, Science Communication, 34(4), 487-519.

12. Faugier J. and Sargeant M. (1997). Samping hard to reach populations, Journal of Advanced Nursing, 26, 790-797.

13. Fauziah, A. (2013). Konsep Pendidikan Akhlak: Studi Komparasi Pada Pemikiran Imam Al Ghazali Dan Syed Muhammad Naquib Al Attas, Doctoral Dissertation, UIN Sunan Ampel, Surabaya.

14. Ferdaus, H., Benjamin, O., Brian, S., William, H. and Adesoji, A. (2003). Product attributes, consumer benefits and public approval of genetically modified foods, International Journal of Consumer Studies, 27(5), 353-365.

15. governance, issues and challenges in Malaysia

16. Habibi-Najafi, M.B. (2006). Food biotechnology and its impact on our food supply, Biotechnology and Biochemistry, 1(1), 22-27.

17. Heckathorn D. (1997). Respondent-driven sampling: A new approach to the study of hidden populations, Social Problems, 44, 174-199.

18. Isa N.M. (2014). Memahami keutamaan dalam menilai makanan yang diubahsuai secara genetik (GMF) daripada perspektif Islam, Persidangan Kebangsaan Etika Kepenggunaan.

19. Isa N.M. (2015). Bioethics in the Malay-Muslim community in Malaysia: A study on the formulation of fatwa on genetically modified food by the National Fatwa Council, Developing World Bioethics, 15(3), 143-151.

20. Jabatan Kemajuan Islam Malaysia (JAKIM) (2009). Keputusan muzakarah Jawatankuasa Fatwa Majlis Kebangsaan bagi Hal Ehwal Agama Islam Malaysia. Putrajaya: Jabatan Kemajuan Islam Malaysia.

21. Jabatan Kemajuan Islam Malaysia (JAKIM) (2011). Hukum memakan makanan terubahsuai genetik (Genetic Modified Food) http://www.e-fatwa.gov.my/fatwa-kebangsaan/hukummemakan-makananterubahsuai-genetik-genetic-modified-food. Accessed on 29 November 2017.

22. Janis, Z.M. (2004). Malaysian Standard MS 1500: 2004 Halal Food-Production, Preparation, Handling and Storage-General Guidelines, Standards \& Quality News July-August, 2-3.

23. Lynn, J.F., Chaya, H., Richard, S. (1995). Genetic engineering and food: what determines consumer acceptance? British Food Journal, 97(8), 31-36.

24. MODIFIED FOOD BY THE NATIONAL FATWA COUNCI

25. Salganik MJ. and Heckathorn DD. (2004). Sampling and estimation in hidden populations using respondent-driven sampling, Sociological Methodology, 34, 193-239.

26. Sazelin, A. and Safiahm S. (2015). Application of Halalan Toyyiban in the Standard Reference for Determining Malaysian Halal Food source from http://www.ccsenet.org/j ournal/index.php/ass/article/viewFile/49684/26783. Accessed on 29 November 2017.

27. Selvarajah, K., Che Musa, C.O., Irsyad, Z., Nazreen, S., Sharifah Alyaa. (2017). The Awareness of Gen Z's toward Halal Food Industry, Management, 7(1), 44-47. 
28. Zurina S. and W.M.N. Wan Siti Khadijah (2012). Halal Traceability Framework for Halal Food Production sources from http://www.thaihalalfoods.com/upload/articles/Researc h6. pdf. Accessed on 12 November 2017.

Conflict of Interest Statement: The authors declare that the research was conducted in the absence of any commercial or financial relationships that could be construed as a potential conflict of interest.

Copyright (c) 2020 A.M.Z., R, R, M.S.K. and Ho Abdullah, S.. This is an open-access article distributed under the terms of the Creative Commons Attribution License (CC BY). The use, distribution or reproduction in other forums is permitted, provided the original author(s) and the copyright owner(s) are credited and that the original publication in this journal is cited, in accordance with accepted academic practice. No use, distribution or reproduction is permitted which does not comply with these terms. 